\title{
33. CRETACEOUS AND PALEOGENE PLANKTONIC FORAMINIFERA, LEG 27 OF THE DEEP SEA DRILLING PROJECT
}

\author{
V. A. Krasheninnikov, Geological Institute of the Academy of Sciences, Moscow, USSR
}

\begin{abstract}
Cretaceous and Cenozoic sediments, penetrated by Sites 259, 260, 261 , and 263 in the eastern part of the Indian Ocean, are mainly brown zeolite clays and turbidites. Small quantities of calcareous clays and nanno ooze with planktonic foraminifera are intercalated with the clays and have Albian, upper Paleocene, and lower Eocene ages.

The Albian sediments at Site 259 are characterized only by Hedbergella species (infracretacea, globigerinellinoides, planispira, amabilis, aff. delrioensis, aff. infracretacea). At Site 260 planktonic foraminifera are more diverse; in addition to the above-mentioned species there are other species of Hedbergella (trocoidea brittonensis) and representatives of Globigerinelloides (eaglefordensis, bentonensis, ultramicra, gyroidinaeformis, aff. maridalensis).

Assemblages of planktonic foraminifera of the upper Paleocene (the Globorotalia velascoensis Zone) at Site 259 consist of comparatively rare species of Acarinina (acarinata, mckannai, primitiva) and Globigerina (chascanona, nana) combined with sporadic Globorotalia (imitata, aff. acuta).

Sediments of the lower part of the lower Eocene at Site 259 are characterized by rare Acarinina (pseudotopilensis, soldadoensis, acarinata, aff. triplex) and casts of Globorotalia from the group of Globorotalia aequa - G. subbotinae-G. marginodentata.

Turbidites contain rather frequently redeposited Cretaceous, Paleogene, and Neogene planktonic foraminifera.
\end{abstract}

\section{LOWER CRETACEOUS (ALBIAN)}

Lower Cretaceous sediments, Albian, with planktonic foraminifera have been identified in two regions of the Indian Ocean-the Perth Abyssal Plain in the south (Site 259) and the Gascoyne Abyssal Plain in the north (Site 260).

\section{Site 260}

Sediments with planktonic foraminifera are brown and yellowish-brown nanno oozes and dark carbonaterich clays in Sample 8, CC and Cores 9, 10, and 11; their thickness is 38 meters. These deposits are underlain by brown clays and nanno oozes with scarce benthonic foraminifera, Radiolaria, and nannoplankton (Core 12). The nannoplankton indicates a middle Albian age (Proto-Decima, this volume). The overlying sediments (Core 8) consist of brown zeolite clays with radiolarians and sporadic agglutinated foraminifera; the questionable Albian age is based on benthonic foraminifera.

Planktonic foraminifera are abundant in most of the samples selected for study: 9-1, 117-119 cm; 9, CC; 10-1, $102-104 \mathrm{~cm} ; 10-2,32-34 \mathrm{~cm} ; 10, \mathrm{CC} ; 11-1,57-59 \mathrm{~cm} ; 11$, CC. They are less abundant in Sample 9-1, 130-132 cm and sporadic in Sample 8, CC.

Hedbergella infracretacea (Glaessner) and $H$. aff. delrioensis (Carsey) prevail among planktonic

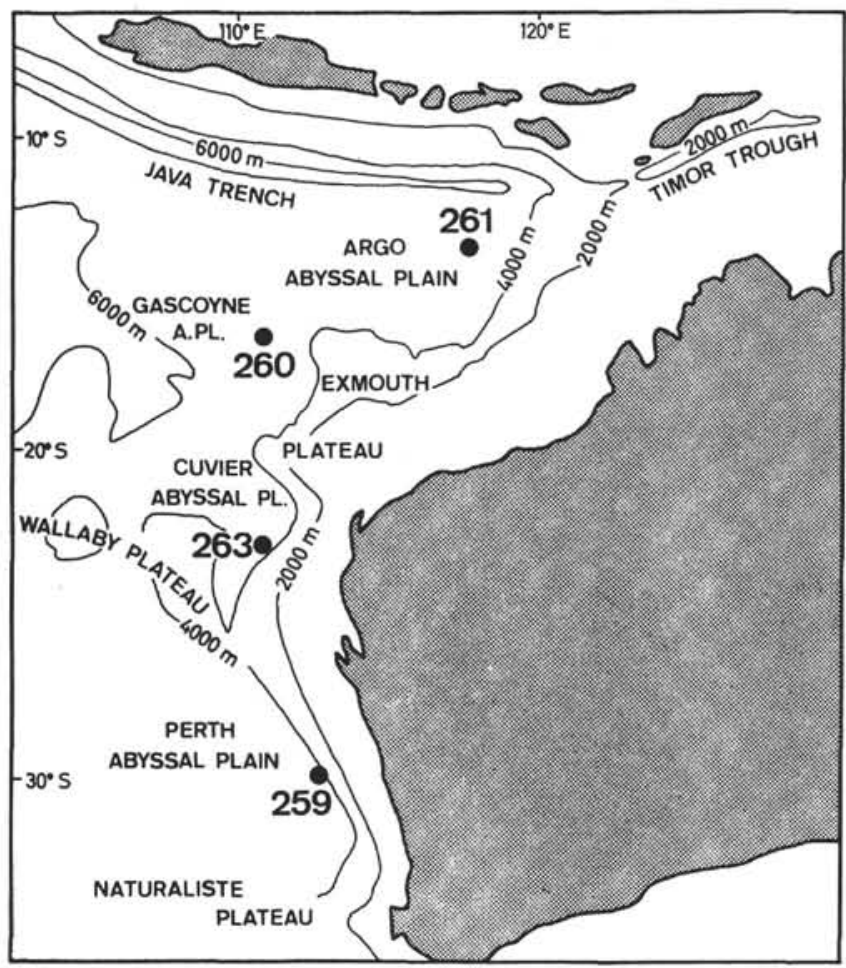

Figure 1. Location of Leg 27 Sites 259, 260, 261, and 263. 
foraminifera. They are accompanied by the less common H. globigerinellinoides (Subbotina), Globigerinelloides eaglefordensis (Moreman), G. bentonensis (Morrow). Hedbergella trocoidea (Gandolfi) and $H$. brittonensis Loeblich and Tappan are numerous in Sample 9, CC, but rare or absent in other samples. Globigerinelloides aff. maridalensis (Bolli), together with sporadic G. ultramicra (Subbotina) are common in Samples 10, CC and 11-1, 57-59 cm; sporadic specimens of Globigerinelloides gyroidinaeformis Moullade occur in Sample 11-1, 57-59 cm.

\section{Site 259}

Lower Cretaceous deposits with planktonic foraminifera at Site 259 are brown, light brown, and yellowish-brown zeolite and clay-rich nanno ooze (Cores 13, 14, 15, 16, and 17). They are approximately 43 meters thick and are underlain by zeolite and cristobalite clays with poor arenaceous foraminifera and Radiolaria. Based on palynomorphs, these sediments are Lower Cretaceous, Aptian in age (Wiseman and Williams, this volume). Overlying sediments (Cores 11, 12) are composed of cristobalite-, zeolite- and nannobearing zeolite clays with nannoplankton, abundant Radiolaria, and sporadic benthonic (calcareous and agglutinated) foraminifera. Based on nannoplankton the age of these deposits is middle Albian, Prediscosphaera cretacea Zone (Proto-Decima, this volume).

Planktonic foraminifera are unevenly distributed at Site 259. They are abundant or numerous in Samples 14$6,20-22 \mathrm{~cm} ; 14$, CC; $15-2,76-78 \mathrm{~cm} ; 15-4,56-58 \mathrm{~cm} ; 16-$ $4,89-91 \mathrm{~cm}$; and rare or sporadic and poorly preserved in Samples 13-1, 80-82 cm; 13-2, 80-82 cm; 13-5, 90-92 $\mathrm{cm} ; 13-6,99-101 \mathrm{~cm} ; 14-2,57-59 \mathrm{~cm} ; 14-3,94-96 \mathrm{~cm} ; 14-$ $4,81-83 \mathrm{~cm} ; 14-5,44-46 \mathrm{~cm} ; 14-6,75-77 \mathrm{~cm} ; 14-6,105-$ $107 \mathrm{~cm} ; 15-1,106-108 \mathrm{~cm} ; 15-6,68-70 \mathrm{~cm} ; 15, \mathrm{CC} ; 16-2$, $90-92 \mathrm{~cm} ; 16-3,93-95 \mathrm{~cm} ; 16, \mathrm{CC} ; 17-2,45-47 \mathrm{~cm} ; 17-3$, $40-42 \mathrm{~cm}$.

Predominant are Hedbergella infracretacea (Glaessner), $H$. aff. infracretacea (Glaessner), $H$. globigerinellinoides (Subbotina), H. planispira (Tappan). Much rarer are $H$. aff. delrioensis (Carsey) and $H$. amabilis Loeblich and Tappan.

\section{Comparison of Foraminifera From Sites 259 and 260}

A comparison of planktonic foraminiferal assemblages from the lower Cretaceous at Sites 259 and 260 shows that they have only three species in common (Hedbergella infracretacea, $H$. globigerinellinoides, and $H$. aff. delrioensis). The assemblage at Site 259 has considerably fewer species than the one at Site 260, and these indicate only an age of Albian s.l. The Hedbergella species continue into the Cenomanian, where they occur with representatives of Rotalipora and Praglobotruncana. The impoverishment of planktonic foraminifera at Site 259 is shown by the absence of the genera Ticinella, Globigerinelloides, Planomalina, and Schackoina. The assemblages at Site 259 are characterized by the continuous presence of Hedbergella aff. infracretacea (Glaessner), H. planispira (Tappan), and, rarer, H. amabilis Loeblich and Tappan, species which play a subordinate role at Site 260 .
The planktonic foraminifera at Site 260 are more diverse and therefore provide a more precise age for the sediments. Species such as Globigerinelloides eaglefordensis (Moreman), G. bentonensis (Morrow), G. ultramicra (Subbotina), Hedbergella brittonensis Loeblich and Tappan, appear in the upper Albian and have a wide distribution in the Cenomanian. Their occurrence together with Hedbergella infracretacea (Glaessner), H. globigerinellinoides (Subbotina), $H$. aff. delrioensis (Carsey), and $H$. trocoidea (Gandolfi) indicates an age within the upper Albian-lower Cenomanian. With Rotalipora and Praeglobotruncana absent, preference is given to an upper Albian age. There is, however, a notable absence at Site 260 of characteristic upper Albian-lower Cenomanian species belonging to the genera Tincinella. Planomalina. Clavihedbergella, Schackoina, and early representatives of Rotalipora and Praeglobotruncana.

If the assemblages of planktonic foraminifera at Sites 259 and 260 are both upper Albian, the richer and more diverse fauna at Site 260 must have been deposited in a different, probably warmer, environment than the fauna at Site 259.

Widely differing views prevail on the subdivision and interpretation of species in the genera Hedbergella and Globigerinelloides. To document the planktonic foraminifera at Sites 259 and 260, a short description, accompanied by scanning electron microscope (SEM) micrographs, is given below. The figured specimens are kept in the Micropaleontological Laboratory of the Geological Institute of the Academy of Sciences of the USSR, Moscow, under Collection Number 4015.

\section{SYSTEMATICS}

\section{Genus HEDBERGELLA Bronnimann and Brown, 1958}

Hedbergella infracretacea (Glaessner)

(Plate 1, Figures 1-3)

1937. Globigerina infracretacea Glaessner, p. 28, fig. 1.

Remarks: The test is small (diameter $0.25-0.15 \mathrm{~mm}$, thickness 0.12 $0.07 \mathrm{~mm})$. The initial whorls $(1-1.5)$ are minute, flat, or slightly elevated above the surface of the last whorl. The last whorl has 4.5-5.5 spherical chambers which increase rapidly in size and which are separated by deep septal sutures. As a result, the test possesses an irregular, oval shape with lobulate outline.

Geographic range: The species was first described by Glaessner (1937) from the Lower Cretaceous of the North Caucasus, USSR, where it is widespread in the Albian, less so in the Cenomanian.

\section{Hedbergella aff. infracretacea (Glaessner) \\ (Plate I, Figures 4-6)}

Remarks: These forms differ distinctly from typical specimens of $H$. infracretacea in having a flattened spiral side with elongate oval chambers on this side of the test.

Dimensions: Diameter $0.32-0.25 \mathrm{~mm}$, thickness $0.13-0.10 \mathrm{~mm}$.

Geographic range: The form has been described from the Albian of the USSR, France, and the Federal Republic of Germany as $H$. infracretacea (Subbotina, 1953, pl. 1, fig. 10a, b, c) or as $H$. aff. infracrefacea (Moullade, 1966, p. 8, fig. 6-9; Risch, 1971, pl. 4, fig. 1113).

It is possible that this form could be distinguished as a new species.

\section{Hedbergella aff. delrioensis (Carsey)}

(Plate 1, Figures 7-9)

Remarks: The morphological characters of $H$. delrioensis (Carsey), 1926 , and $H$. infracretacea (Glaessner), 1937, are so similar, that the 
two species could be synonymous. Loeblich and Tappan (1961) maintain that $H$. delrioensis differs from $H$. infracretacea in being twice its size (diameters of hypotypes of $H$. detrioensis range from 0.23 to $0.57 \mathrm{~mm}$ ); they regard $H$. infracretacea as a junior synonym of $H$. delrioensis. Certainly, the dimensions of the test are not a reliable feature for distinguishing these two species.

Numerous specimens of Hedbergella in Leg 27 material differ from typical $H$. infracretacea in having a slightly convex spiral side (initial whorls are somewhat elevated above the final whorl), and a more compact arrangement of spherical chambers (the test becomes more rounded in shape, retaining a lobulate outline). These Hedbergella forms resemble $H$. delrioensis, but have smaller dimensions (diameter $0.20-0.28 \mathrm{~mm}$, thickness $0.12-0.15 \mathrm{~mm}$ ). They are here tentatively included in $H$. aff. delrioensis.

The taxonomic position of $H$. delrioensis and $H$. infracretacea requires a close variability study of these species and comparison with Albian topotypes from the USSR and the United States.

\section{Hedbergella planispira (Tappan)}

(Plate 1, Figures 10-12)

1940. Globigerina planispira Tappan, p. 122, pl. 19, fig. 12.

Description: This species is characterized by its very low trochospiral coiling. On the spiral side, the initial coil is lower than the final whorl. The test is compressed, with almost parallel spiral and umbilical sides; in peripheral view, it resembles the test of Globigerinelloides. The last whorl consists of six to seven moderately convex chambers, increasing regularly in size as added.

Dimensions: Diameter 0.25-0.42 mm, thickness 0.12-0.18 mm.

Remarks: The morphological characters of Hedbergella planispira from the Albian of the Indian Ocean and topotypes from the Cenomanian of the United States are practically identical. However, the dimensions of the American forms are considerably smaller (diameter 0.11-0.26 mm), according to Loeblich and Tappan (1961). This explains why these authors consider the small $H$. globigerinellinoides (Subbotina) as junior synonym of $H$. planispira (Tappan).

\section{Hedbergella globigerinellinoides (Subbotina}

(Plate 1, Figures 13-15)

1949. Globigerina globigerinellinoides Subbotina, p. 32, pl. 2, fig. 1116.

Description: The small test (diameter $0.14-0.25 \mathrm{~mm}$, thickness 0.07 $0.10 \mathrm{~mm}$ ) of this species is strongly compressed in a dorsoventral direction, with flattened spiral and umbilical sides. The initial coil is usually in the same plane as the last whorl, sometimes slightly below or above its surface. The last whorl contains six to seven tightly arranged, spherical chambers, very slowly increasing in size as added, separated by deep, straight septal sutures. Viewed from the spiral side, the test has almost a circular form, with a slightly lobulate outline.

Remarks: The holotype of this species is from the Albian of the southwestern Caucasus (near Gelendjic, U.S.S.R.). The species is frequent in the Albian, especially the upper Albian, of the Caucasus and Crimea and extends into the lower part of the Cenomanian. Topotypes of $H$. globigerinellinoides differ from the Indian Ocean specimens in their smaller dimensions (Diameter 0.13-0.15 mm, thickness $0.05-0.08 \mathrm{~mm}$ )

The species is undoubtedly similar to $H$. planispira (Tappan), differing in its small, tightly arranged spherical chambers, and almost circular form of the test with a slightly lobulate outline.

\section{Hedbergella amabilis Loeblich and Tappan}

(Plate 2, Figures 1-3)

1961. Hedbergella amabilis Loeblich and Tappan, p. 274, pl. 3, fig. 110.

Description: The small (diameter 0.15-0.20 mm, thickness 0.05-0.06 $\mathrm{mm}$ ), flat test is strongly compressed in the dorsoventral direction. The initial coil lies in the plane of the final whorl or slightly above it. The final whorl contains five to six spherical chambers loosely arranged and gradually increasing in size as added. The outline of the test is distinctly lobulate. This feature differs markedly from other species of Hedbergella and makes $H$. amabilis similar to representatives of Clavihedbergella.
Geographic range: Hedbergella amabilis has been described by Loeblich and Tappan (1961) from the Cenomanian Britton Clay, Eagle Ford Group. Texas. Dimensions of the Albian Indian Ocean specimens are two times smaller. Their test shape is identical with some paratypes of H. amabilis (Loeblich and Tappan, 1961, pl. 3, fig. $2,3,5,6$ ), but differs from the holotype (pl. 3, fig. 1) in having a less strongly incised test outline.

\section{Hedbergella trocoidea (Gandolfi)}

(Plate 2, Figures 4-6)

1942. Anomalina lorneiana d'Orbigny var. trocoidea, Gandolfi, p. 98, pl. 2, fig. 1; pl. 4, fig. 2,3 ; pl. 13, fig. 2,5 .

Description: The test is low trochospiral, flattened on the spiral side and convex on the umbilical side. The initial coil is in the plane of the last whorl or is slightly elevated above its surface on the spiral side. The last whorl contains six to seven tightly coiled chambers, gradually increasing in size as added. Chambers are moderately convex, spherical on the spiral side and subtriangular on the umbilical side. The outline of the test is slightly lobulate. The characteristic features of the species are the tight arrangement of chambers and the low trochospiral coiling.

Dimensions: Diameter 0.25-0.35 mm, thickness 0.12-0.17 mm.

Stratigraphic range: Hedbergella trocoidea has a rather wide stratigraphic distribution: Aptian-Cenomanian.

\section{Hedbergella brittonensis Loeblich and Tappan}

(Plate 2, Figures 7-9)

1961. Hedbergella brittonensis Loeblich and Tappan, p. 274, pl. 4, fig. $1-8$

Description: The test is medium or high trochospiral, with a convex spiral and a flattened umbilical side. The last whorl consists of six to seven, seldom eight, tightly arranged chambers, moderately convex or spherical on the spiral, subtriangular on the umbilical side. The outline of the test is slightly lobulate, the wall distinctly spinose.

Dimensions: Diameter 0.25-0.36 mm, thickness 0.17-0.25 mm.

Remarks: According to Bandy (1967), Eicher (1969), and Porthault (1969), $H$. brittonensis is a junior synonym of $H$. portsdownensis (Williams-Mitchell, 1948). The latter is characterized by a low trochospiral test with a rather loose arrangement of chambers and by a lobulate outline.

Numerous low trochospiral tests are included among specimens of $H$. brittonensis from the Albian sediments of the Indian Ocean but they always possess tight coiling and a slightly lobulate outline. Therefore, $H$. brittonensis and $H$. portsdownensis are here regarded as two different species.

Loeblich and Tappan (1961) described $H$. brittonensis from the Cenomanian of Texas.

\section{Genus GLOBIGERINELLOIDES Cushman and Ten Dam, 1943}

\section{Globigerinelloides eaglefordensis (Moreman)}

(Plate 2, Figures 10, 11)

1927. Anomalina eaglefordensis Moreman, p. 99, pl. 16, fig. 9.

Description: The test is planispiral, biumbilicate, compressed, and partially evolute, with a rounded, peripheral margin and a lobulate outline. The last whorl contains five to eight, usually six subspherical chambers separated by deep septal sutures. Chambers increase rather rapidly in size as added, and the test is somewhat elongate. The thickness of the chambers increases slowly and regularly.

Dimensions: Diameter 0.22-0.38 mm, thickness 0.17-0.20 mm.

Remarks: This species has been described from the latest AlbianCenomanian of many countries.

\section{Globigerinelloides bentonensis (Morrow)}

(Plate 2, Figures 12, 13)

1934. Anomalina bentonensis Morrow, p. 201, pl. 30, fig. 4a-b.

Description: This species is distinguished from $G$. eaglefordensis (Moreman) in that the test is more inflated and less evolute, with the initial whorls hardly visible. The umbilical deepenings have a smaller size but are deeper; the chambers increase in thickness as added. The peripheral margin is broadly rounded. 
Dimensions: Diameter 0.30-0.38 mm, thickness 0.20-0.26 mm.

Remarks: The question of Globigerinelloides eaglefordensis and $G$. bentonensis being different is complex. Moullade (1969) considers the latter a junior synonym of $G$. eaglefordensis. Loeblich and Tappan (1961), Pessagno (1969), Eicher (1969), and Dabaghyan (1973) treat them as independent species. A similar view is expressed by Risch (1971) who, however, places some of the $G$. eaglefordensis specimens described by Moullade, 1969; Ayala Castanares, 1962; and Loeblich and Tappan,1961; in synonymy with $G$. bentonensis. The investigations of the planktonic foraminifera from the Albian of the eastern Indian Ocean suggests that $G$. eaglefordensis and $G$. bentonensis are separate species. These taxonomic contradictions have no bearing on the stratigraphic distribution; both $G$. bentonensis and $G$. eaglefordensis have the same range, uppermost Albian-Cenomanian.

Globigerinelloides aff. maridalensis (Bolli)

(Plate 2, Figures 14-15)

1959. Planomalina maridalensis Bolli, p. 261, pl. 20, fig. 4-6.

Description: The test is planispiral and slightly evolute, with thin walls. The last whorl contains four to five oval, inflated chambers rapidly increasing in size as added. The outline of the test is lobulate.

Remarks: Compared with the holotype, the Site 260 specimens figured as Globigerinelloides aff. maridalensis have similar, but slightly less oval-shaped chambers in the last whorl. Also, the original Trinidad specimens are less evolute than those at Site 260. For comparison with these specimens (Plate 2, Figures 14, 15) see the specimen in Bolli (1959, pl. 20, fig. 4), which clearly show these differences.

There is also a certain similarity between $G$. aff. maridalensis of Site 260 and $G$. blowi (Bolli), originally described from the Aptian Leupoldina protuberans Zone of Trinidad, and later reported from Western Europe and the U.S.S.R. However, chambers are more spherical and less oval in this species (Bolli, 1959, pl. 20, fig. 2a, 3).

G. maridalensis was originally described from the Globigerinella barri Zone of Trinidad, tentatively placed there into the uppermost Aptian/lower Albian. This compares fairly well with the age of the Site 260 specimens which are regarded as only slightly younger (probably upper Albian). The possible slight age difference between the Trinidad and the Site 260 specimens may account for the morphological differences.

\section{Globigerinelloides ultramicra (Subbotina)}

(Plate 2, Figure 16)

1949. Globigerinella ultramicra Subbotina, p. 33, pl. 1, fig. 17, 18.

Description: The test is very small (diameter $0.15-0.18 \mathrm{~mm}$, thickness $0.05-0.07 \mathrm{~mm}$ ), planispiral, slightly evolute, strongly compressed, and circular in equatorial view, with a lobulate outline. The umbilical deepenings are flat. The last whorl consists of six to eight spherical chambers of almost equal size. The wall is very thin.

Range: The species has been found in the upper AlbianCenomanian of the Caucasus, Crimea, and the Carpathians (U.S.S.R.)

\section{Globigerinelloides gyroidinaeformis Moullade}

(Plate 2, Figures 17a-c)

1966. "Globigerinelloides" gyroidinaeformis Moullade, p. 128, pl. 9, fig. 16-22.

Description: The test is pseudospiral, involute, irregularly circular in equatorial view and slightly lobulate and broadly oval in peripheral view. The peripheral margin is rounded, and the umbilical deepenings are very small. The last whorl contains four to five convex chambers, tightly arranged, gradually increasing in size as added. The last chamber is sometimes inflated.

Dimensions: Diameter 0.31-0.42 mm, thickness 0.28-0.35 mm.

Range: The species has been described from the lower and middle Albian of France (Moullade, 1966) and the Federal Republic of Germany (Risch, 1971).

\section{UPPER CRETACEOUS}

Upper Cretaceous sediments consisting chiefly of brown, zeolitic, noncalcareous clays were penetrated at Sites 260 and 261. The sediments apparently were deposited below the lysocline and contain only autochthonous, benthonic, agglutinated foraminifera (Upper Cretaceous benthonic agglutinated foraminifera, Leg 27 of the Deep Sea Drilling Project, this volume).

Some samples of brown clay at Site 260 , Core 6, Section 1, Intervals $71-73 \mathrm{~cm}, 85-87 \mathrm{~cm}, 106-108 \mathrm{~cm}$, and $139-141 \mathrm{~cm}$, include redeposited planktonic foraminifera. Their redeposited character is evident from the mixing of species of different age. Three groups of species are distinguished on the basis of age: (1) Albian-Cenomanian-Hedbergella wachitaensis (Carsey), $H$. simplicissima Magné and Sigal, $H$. planispira (Tappan), H. caspia Vassilenko, H. brittonensis Loeblich and Tappan, and Clavihedbergella simplex (Morrow); (2) Cenomanian-Schackoina cenomana (Schacko), Rotalipora apenninica (O. Renz); (3) upper Turonian-Coniacian-Praeglobotruncana imbricata (Mornod), P. inflata Gandolfi, Globotruncana lapparenti Brotzen, G. ex gr. coronata Bolli, Heterohelix globulosa (Ehrenberg). Globotruncanids restricted to the late Upper Cretaceous (Santonian, Campanian, Maestrichtian) were not observed.

Some tests of planktonic foraminifera are broken. Unbroken tests are frequently small, apparently a result of sorting in the process of transportation. These juvenile stages of Praeglobotruncana and Globotruncana are difficult to determine precisely on the species level. Evidently, the planktonic foraminifera, together with representatives of redeposited benthonic foraminifera (Stensiona, Valvulineria, Globorotalites, Reussella, etc.) are preserved in the noncarbonate brown clays as a result of a rapid rate of sedimentation.

The planktonic foraminiferal fauna consist of species indicative of three different ages (Albian-Cenomanian, Cenomanian, and upper Turonian-Coniacian). These foraminifera are thought to have been carried down by turbidity currents from shallower calcareous sediments into the abyssal clays. Thus, the youngest species, indicating a maximum age of upper TuronianConiacian, may also be reworked, and the sediments including the assumed autochthonous agglutinated foraminifera consequently will still be younger.

\section{UPPER PALEOCENE-LOWER EOCENE}

Deep-water upper Paleocene-lower Eocene sediments consisting of brown clays, and zeolite-bearing clays with intercalations of nanno ooze occur in the Perth Abyssal Plain (Site 259, water depth $4706 \mathrm{~m}$ ). The upper Paleocene rests directly on the Lower Cretaceous (Albian), resulting in a large hiatus that not only embraces the Upper Cretaceous and lower Paleocene, but also the lower part of the upper Paleocene. The lower Eocene is overlain by brown zeolite clays devoid of fossils.

Sediments of both the upper Paleocene and the lower Eocene are characterized by few planktonic foraminifera with little specific variation. The brown clays of Cores 8, 7, 6, and probably Core 5 (Sections 6, 5) are assigned to the upper Paleocene. These sediments contain an assemblage of planktonic foraminifera consisting of relatively rare Acarinina acarinata Subbotina, 
A. mckannai (White), A. primitiva (Finlay), A. sp., Globigerina chascanona Loeblich and Tappan, G. nana Khalikov, Globorotalia imitata Subbotina, Chilog uembelina aff. wilcoxensis(Cushman and Ponton), and rare Globorotalia aff. acuta Toulmin. The most common species is Acarinina acarinata.

Based on planktonic foraminifera, the deposits are assigned to the upper part of the upper Paleocene, the Acarinina acarinata Zone of the stratigraphic zonal scale of the U.S.S.R. Paleogene (the Crimea-Caucasian area). This zone corresponds with the Globorotalia velascoensis Zone of the Paleogene of Trinidad. This agrees with available data on nannoplankton, Discoaster multiradiatus Zone, uppermost upper Paleocene (ProtoDecima, this volume).

The upper Paleocene planktonic foraminifera are accompanied by much more numerous and specifically diverse benthonic foraminifera with calcareous and agglutinated tests. They include species of Tappanina, Aragonia, Anomalina, Cibicides, Gavelinella, Cassidulina, Pleurostomella, Pullenia, Gyroidinoides, Eponides, Lenticulina, Nodosaria, Globulina, Guttulina, Bulimina, Lagena, Virgulina, Nuttallides, Angulogerina, Textularia, Verneuilina, Dorothia, Eggerella, Tritaxia, Glomospira.

The Paleocene-Eocene boundary (Pseudohastigerina Datum) at Site 259 could not be drawn accurately on planktonic foraminifera. Brown zeolite clays of Core 5, Sections 1-4, and Core 4, Sections 5-6, contain sporadic A carinina acarinata Subbotina, A. primitiva (Finlay), A. sp., Globigerina sp., Chiloguembelina aff. wilcoxensis (Cushman and Ponton). These sediments should be placed either into the top Paleocene or bottom lower Eocene. The nannoplankton indicate that they belong to the lowermost part of the lower Eocene (Tribrachiatus contortus and Discoaster binodosus zones).

Unquestionably, lower Eocene planktonic foraminifera have been established in the brown clays of Core 4, Section 3. These include sporadic casts of Globorotalia from the group $G$. aequa Cushman and Renz and $G$. subbotinae Morozova and the group $G$. subbotinae Morozova and G. marginodentata Subbotina, and rare tests of Acarinina pseudotopilensis Subbotina, A. aff. triplex Subbotina, A. soldadoensis (Bronnimann), A. acarinata Subbotina, A. aff. primitiva (Finlay), Globigerina sp., and Chiloguembelina aff. wilcoxensis (Cushman and Ponton). These assemblages are assigned to the Globorotalia subbotinae and the Globorotalia formosa formosa zones (lower part of the lower Eocene). The nannoplankton yield a similar age, Marthasterites tribrachiatus Zone (Proto-Decima, this volume).

The nanno ooze and brown zeolite clay of Core 4 , Sections 1, 2 belong to the upper part of the lower Eocene, Discoaster lodoensis Zone (Proto-Decima, this volume). Planktonic foraminifera are practically absent in these sediments.

The poor assemblages of planktonic foraminifera from the upper Paleocene-lower Eocene of the Perth Abyssal Plain consist mostly of Acarinina and Globigerina with specimens of Globorotalia being extremely, rare. These assemblages resemble associations of planktonic foraminifera of moderate latitudes, or even boreal regions. For instance, upper Paleocene (the Globigerina nana-Acarinina primitiva local biostratigraphic zone) and lower Eocene (the
Globigerina turgida-Acarinina triplex local biostratigraphic zone) deposits of the Kamchatka Peninsula are characterized by similar poor assemblages of planktonic foraminifera consisting of Acarinina and Globigerina species (Serova, 1967).

However, the impoverishment of planktonic foraminifera in the upper Paleocene and lower Eocene deposits of the Perth Abyssal Plain and the absence of representatives of Globorotalia among them can also be related to selective dissolution. The brown clay of Core 4 , for instance, contains only casts of Globorotalia and Acarinina. To solve this problem unequivocally (i.e., to establish the factors causing the impoverishment of planktonic foraminifera in the upper Paleocene-lower Eocene of the Perth Abyssal Plain) is rather difficult now.

\section{ACKNOWLEDGMENTS}

The SEM micrographs were taken by H. E. Franz under the direction of H. M. Bolli, Swiss Federal Institute of Technology, Zurich.

\section{REFERENCES}

Ayala-Castanares, A., 1962. Morfologia y Estructura de Alguras foraminiferos Planctovicos del Cenomaniano de Cuba: Soc. geol. Mexicana Bol., v. 25, p. 1-62.

Bandy, O. L., 1967. Cretaceous planktonic foraminiferal zonation: Micropaleontology, v. 13, p. 1-31.

Bolli, H. M., 1959. Planktonic foraminifera from the Cretaceous of Trinidad, B.W.I.: Am. Paleontol. Bull., v. 39, p. 257-277.

Dabaghyan, N. V., 1973. On classification of Planomalinidae. Voprosi Micropaleontol., no. 16 (in Russian).

Eicher, D. L., 1969. Cenomanian and Turonian planktonic foraminifera from the western interior of the United States: Internatl. Conf. Plankt. Microfoss. 1st, Proc., Leiden (Brill), p. $163-174$.

Loeblich, A. R. and Tappan, H., 1961. Cretaceous planktonic foraminifera: Part 1, Cenomanian: Micropaleontology, v. 7, p. $257-304$.

Moullade, M., 1966. Etude stratigraphique et micropaléontologique du Crétacé inférieur de la "Fosse Vocontienne": Doc. Lab. Géol. Fac. Sci., Lyon, N 15, p. 1-369. 1969. Sur l'importance des phénomènes de convergence morphologique chez les Foraminiferes planctoniques du Crétacé inférieur: Internatl. Conf. Plankt. Microfoss. Leiden (Brill), 1st, Proc., p. 460-467.

Pessagno, E. A., 1969. Cenomanian-Turonian (Eaglefordian) stratigraphy in the western Gulf Coastal Plain area: Internatl. Conf. Plankt. Microfoss., 1st, Proc., Leiden (Brill), p. 509-525.

Porthault, B., 1969. Foraminiferes planctoniques et biostratigraphie du Cénomanien dans le sud-est de la France: Internatl. Conf. Plankt. Microfoss. 1st, Proc., Leiden (Brill), p. 526-546.

Risch, H., 1971. Stratigraphie der Höheren Unterkreide der Bayerischen Kalkalpen mit Hilfe von Mikrofossilien: Paleontographica, Bd. 138, Abt. A. p. 1-80.

Serova, M. J., 1967. The zonal scale of the Paleogene deposits of the north-western part of the Pacific province and their correlation to the Tethys deposits: In Tertiary correlations and climatic changes in the Pacific: Pacific Sci. Congr. Eleventh Symp. 25, p. 21-27.

Subbotina, N. N., 1953. Globigerinidae, Hantkeninidae and Globorotaliidae: VNIGRI Trans., new ser., $\mathrm{N}$ 76. (in Russian), p. 1-239. 


\section{PLATE 1}

Figures 1-3 Hedbergella infracretacea (Glaessner). Sample 260-10-1, 102-104 cm, $\times 200$.

1. Spiral view.

2. Peripheral view.

3. Umbilical view.

Figures 4-6 Hedbergella aff. infracretacea (Glaessner). Sample 259-15-4, 56-68 cm, $\times 150$.

4. Spiral view.

5. Peripheral view.

6. Umbilical view.

Figures 7-9 Hedbergella aff. delrioensis (Carsey). Sample 25914-6, 20-22 cm,

7. Spiral view, $\times 150$.

8. Peripheral view, $\times 180$.

9. Umbilical view, $\times 180$.

Figures 10-12 Hedbergella planispira (Tappan). Sample 259-15-4, $56-58 \mathrm{~cm}$,

10. Spiral view, $\times 150$.

11. Peripheral view, $\times 100$.

12. Umbilical view, $\times 100$.

Figures 13-15 Hedbergella globigerinellinoides (Subbotina). Sample 259-16-14, 89-91 cm, $\times 150$.

13. Spiral view.

14. Peripheral view.

15. Umbilical view, 


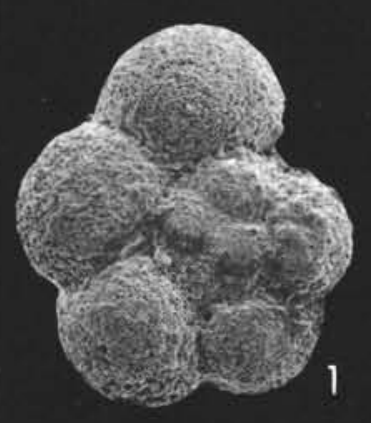

PLATE 1
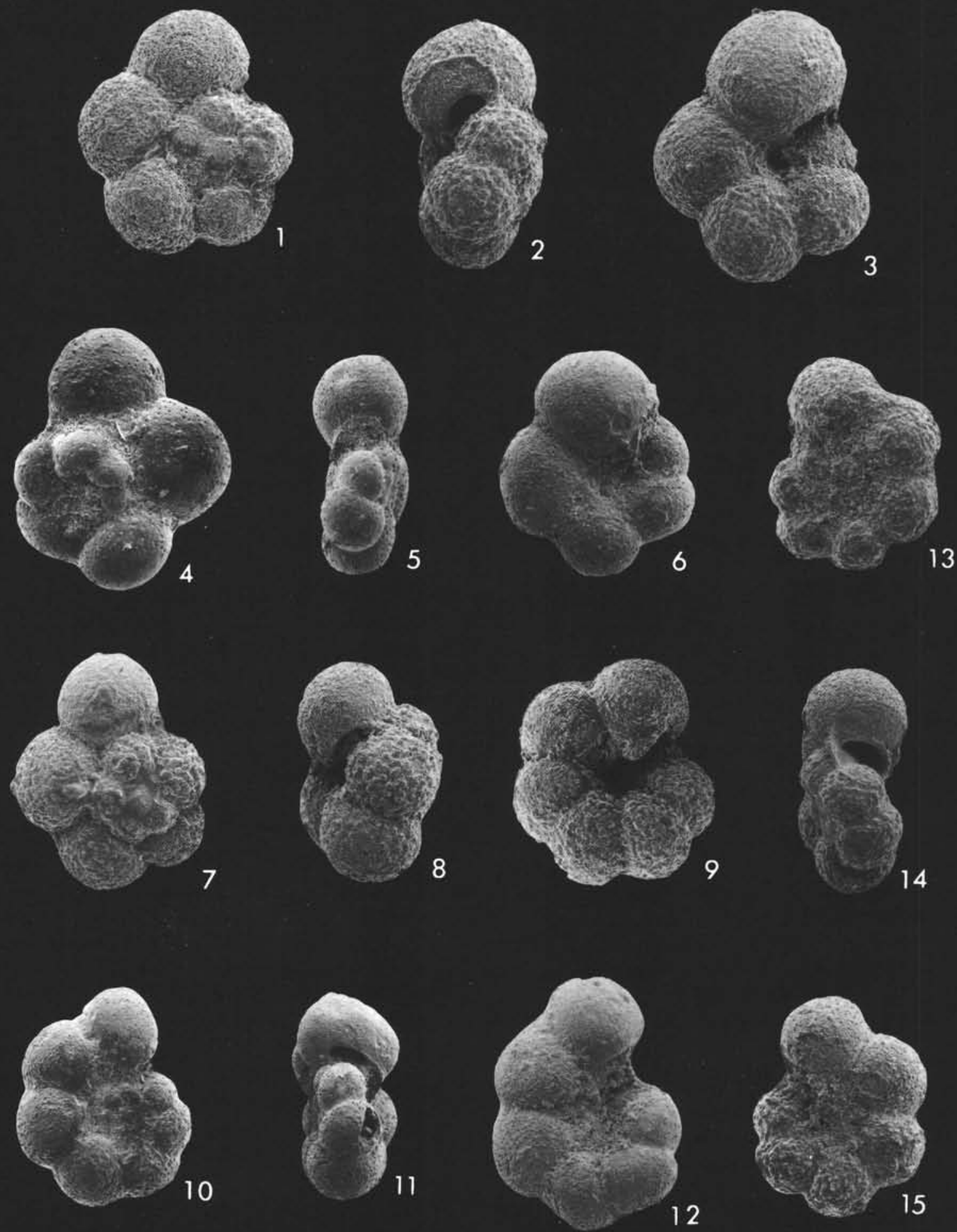


\section{PLATE 2}

Figures 1-3 Hedbergella amabilis Loeblich and Tappan. Sample 259-16-4, 89-91 cm.

1. Spiral view, $\times 200$.

2. Peripheral view, $\times 250$.

3. Umbilical view, $\times 250$.

Figures 4-6 Hedbergella trocoidea (Gandolfi). Sample 260-9, $\mathrm{CC}, \times 120$.

4. Spiral view.

5. Peripheral view.

6. Umbilical view.

Figures 7-9 Hedbergella brittonensis Loeblich and Tappan. Sample 260-9, CC, $\times 120$.

7. Spiral view.

8. Peripheral view.

9. Umbilical view.

Figures 10,11 Globigerinelloides eaglefordensis (Moreman). Sample 260-10-1, 102-104 cm, $\times 100$.

10. Lateral view.

11. Peripheral view.

Figures 12,13 Globigerinelloides bentonensis (Morrow). Sample 260-11-1, 57-59 cm.

12. Lateral view, $\times 100$.

13. Peripheral view, $\times 120$.

Figures 14, 15 Globigerinelloides aff. maridalensis (Bolli). Sample 260-10, CC.

14. Lateral view, $\times 150$.

15. Peripheral view, $\times 180$.

Figure $16 \quad$ Globigerinelloides ultramicra (Subbotina). Sample 260-11-1, 57-59 cm. Lateral view, $\times 250$.

Figure 17a-c Globigerinelloides gyroidinaeformis Moullade. Sample 260-11-1, 57-59 cm, $\times 100$.

17a. Lateral view, slightly oblique.

17b. Peripheral/apertural view.

17c. Peripheral view. 
Plate 2
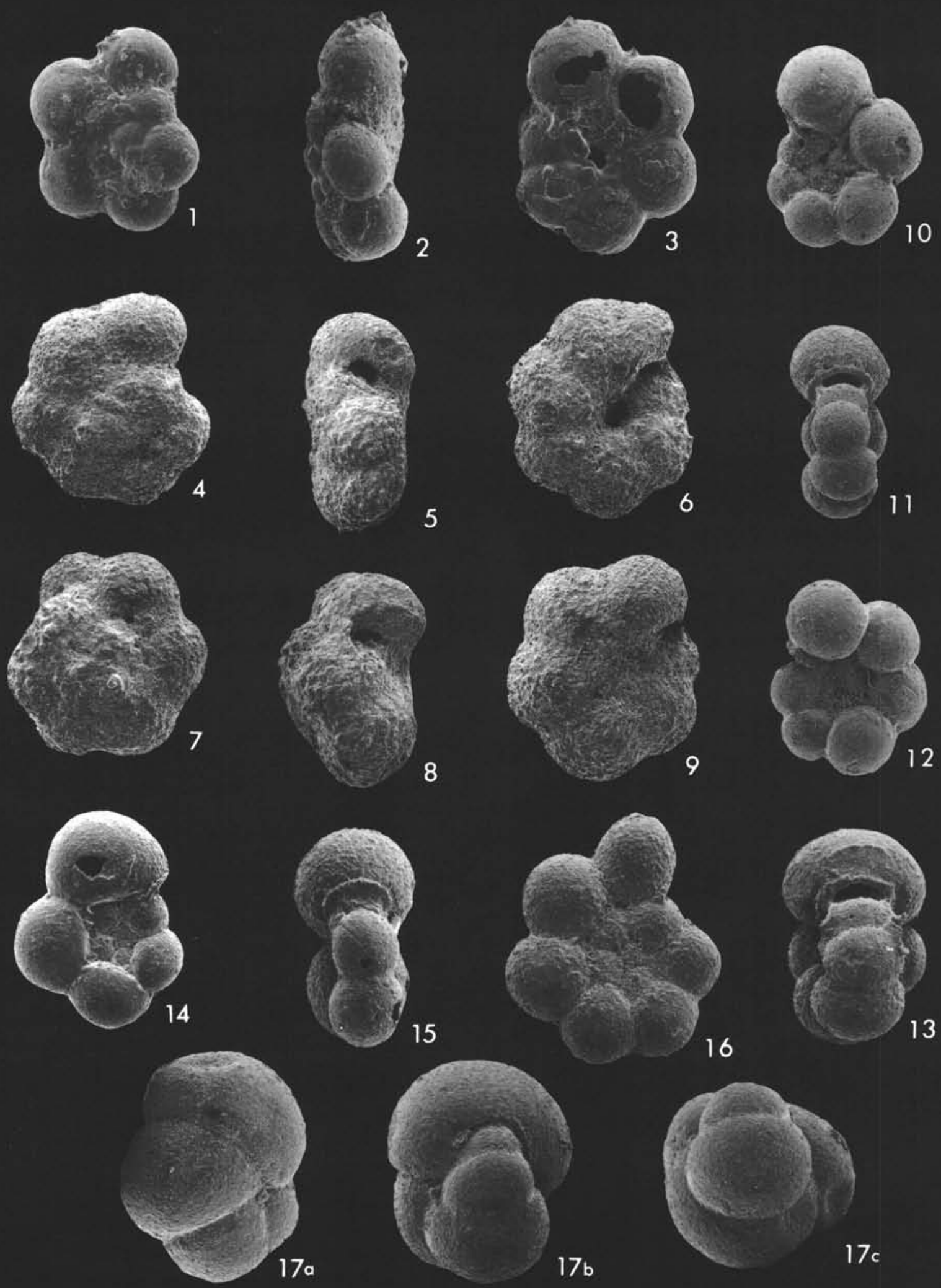